\title{
The Paradox of the Concept of Sustainable Development under Nigeria's Environmental Law
}

\author{
Dr S. Gozie Ogbodo \\ Faculty of Law, University of Benin, P.M.B 1154, Benin City, Nigeria \\ Tel: 112-3480-5843-6456 E-mail: gozieogbodo@yahoo.com
}

\begin{abstract}
The concept of sustainable development is not novel. However, the concept has become so widely embraced beyond the initial application within the limited environmental jurisprudence. In the process, two Schools of Thought have evolved and are fiercely battling for dominance. They are the Positivists/Optimists on the one hand and the Negativists/Pessimists, on the other hand. While the Positivists/Optimists insist on promoting development for the mutual benefit of both the present and future generations; the Negativists/Pessimists insist on restricting development in the same name of sustainable development. Nigeria has wisely embraced a holistic approach to the concept of sustainable development by meshing both their development aspirations with environmental consciousness. In the same vein, both the needs of the present generation and future generation are safeguarded. This work aims at analysing the position of Nigeria in their acceptance and application of the concept under their environmental law.
\end{abstract}

Keywords: Sustainable development, Schools of thought, Nigeria, Environmental jurisprudence, Environmental law

\section{Introduction}

The concept of sustainable development is not novel (Note 1). Infact, it has been known and canvassed, admittedly with less zeal, for decades. The concept has, however, become quite 'politically correct', that it has been generously applied to other socio-economic areas like health, education, economy, etc, in addition to the original application within the environmental jurisprudence. Indeed, the popularity of the concept has generated a growing literature industry such as the Journal of Sustainable Development, the International Journal of Sustainable Development, the International Journal of Sustainable Development and World Ecology and Sustainable Development International. In the field of environmental law, particularly beginning from 1987 (Note 2), it has formed the crux of both municipal and international environmental laws.

Presently, two conflicting Schools of Thought on the sustainable development concept battle fiercely for dominance. First is the school, which claims to "represent the interests of the environment, consumers, the poor and the sick". This group squarely blames the developed and wealthy countries for the world's "poverty, environmental degradation, disease and other problems" by alleging that "people in the rich world consume too great a proportion of the world's resources and emit too great a proportion of the world's pollution". The solution, asserts this group, is to limit the excessive use of the world's resources by the rich countries and their economic agents represented by the trans-national companies (TNCs) as well as imposing restrictions on international trade. For the purposes of this work, we shall classify this group as the Negative/Pessimist School. (Note 3)

The countervailing view, represented by the second school of thought, attempts to shift the blame from the developed countries to the developing countries. They assert that the problems are principally created by the governments of these poor and developing countries in their adoption of policies which are anything but sustainable. In other words, those policies, which attempt to centrally plan the economies; lack property rights enforcement, perpetuate bureaucratic bottlenecks, etc, consequentially create unsustainable development problems. In the same vein, we shall classify this group as the Positive/Optimist School. (Note 4)

As a developing country, Nigeria is struggling to embrace the concept of sustainable development. We shall, therefore, analyse the position of Nigeria in their acceptance and application of the concept with particular reference to their environmental law.

\section{Conceptual/Definitional issues}

In order to better appreciate the hue and cry with respect to the concept of sustainable development, it will be wise to pause and ask the questions, "What is sustainable development?" and "What is the environment.?" Let us take these questions seriatim.

\subsection{Sustainable Development}

The United Nations Environment Programme (UNEP) defined "sustainability" as follows (Note 5):

The intensified and sustainable demand for land, water, marine and coastal resources resulting from the expansion of agriculture and uncontrolled urbanization leading to increased degradation of natural ecosystems and erode the life supporting system that upholds human civilization. Caring for natural resources and promoting their sustainable use is an essential response of the world community to ensure its own survival and well-being. 
"Development", on the contrary, has been defined by the United Nations Declaration on the Right to Develop as (Note 6):

A comprehensive economic, cultural and political process, which aims at the constant improvement of the well being of the entire population and of all individuals on the basis of their active, free and meaningful participation in development and in the fair distribution of benefits resulting therefrom.

Pursuant to the Negative school of thought, Judge Nagendra Singh, described the concept of sustainable development as follows (Note 7):

"The right to development does, however, have certain limitations in as much as it cannot be accepted at the expense of the community or even at the expense of neighbouring state whose prospect may be jeopardized". (emphasis added)

But the most popular definition appears to be contained in the Brundtland Report of the United Nations Commission on Environment and Development (Note 8) which defined the concept as, "development that meets the need of the present without compromising the ability of future generations to meet their own needs." In essence, the objectives of the concept of sustainable development include ensuring that there are enough resources for the human population as a whole; that these resources are distributed to benefit as many as possible; and that economies be developed while protecting the environment for the benefit of all present and future generations (Note 9). It is worthy of note that the Brundtland Report's definition was accepted and formalized at the United Nations Conference on Environment and Development at Rio de Janeiro in 1992.

\subsection{Nigerian Environment}

The primary Nigerian law on the environment, the NESREA Act, defines 'environment' as follows (Note 10):

"Environment" includes water, air, land and all plants and human beings or animals living therein and the inter-relationships which exist among these or any of them."

This definition comprehensively takes cognizance of, not only the physical components of the Nigerian environment, but also, the human or animal component. It certainly recognizes not just the human or animal component, but the interaction among the different components and follows the definition of the environment, which stated as follows (Note 11):

The system of abiotic, biotic, and socio-economic components with which man interacts and simultaneous to which he adopts and transforms and uses in order to satisfy his needs.

Black's Law Dictionary, however, defines the environment as (Note 12):

The totality of physical, economic, cultural, aesthetic and social circumstances and factors, which surround and affect the desirability and value of property and which also affect the quality of people's lives.

This definition is very limited and essentially ignores the presence and interaction of man or animal in the environment. Consequently, we shall also ignore this limited definition and proceed with the more comprehensive ones.

\section{Origin of Concept}

\subsection{Historical}

As we stated earlier, the origin of the concept dates back to many decades ago. In the United States of America, for instance, two contending views of the concept have battled for prominence. The Preservationists focus on protecting the environment in its natural state, "whether for moral, esthetic, economic, or recreational purposes" (Note 13). The Conservationists, on the contrary, focus "on protecting the health of humans, animals, and plants from the polluting effects of human activity." (Note 14)

Initially, Preservationism was more popular and its popularity was manifested in the creation of the US National Parks and the Federal Reserve Lands. National legislations were also passed pursuant to this campaign. For example, the Wilderness Act, the National Historic Preservation Act, etc., are some of the legislative accomplishments of this movement.

Later, however, Conservationism took over because it preached a more appealing theme of "the greatest good of the greatest number in the long run" (Note 15). By implication, at the time, Conservationism campaigned "to limit the use and development of federal natural resources so that they would not destroy the system that created and maintained them" (Note 16). This campaign has metamorphosed into what we presently describe as the concept of sustainable development. It is noteworthy, though, to clarify that although the Preservationists and the Conservationists preached environmental values, both conflicted because while the former preached 'non-use values', the latter preached 'use values.'

Another source of the concept, we are told, derives from the biological concept of 'sustainable yield'. This approach assesses the rate at which species can be reasonably marketed with a view to sustaining the continuity of their population. Although this source is limited to the world's species, it conveniently covers the essence of 
Conservationism. Thus, it focuses on the protection of animals (species) and, more importantly, the environmental value anchored on reasonable 'use value'.

Indeed, the concept of sustainable development has been expanded to encompass four interpretations as follows (Note 17):

(1) The need to preserve natural resources for the benefit of future generations (the principle of "intergenerational equity")

(2) The need to exploit natural resources in a manner which is sustainable or prudent (the principle of "sustainable use")

(3) The equitable use of natural resources by taking into consideration the needs of others to the use and enjoyment of the scarce or finite resources (the principle of "equitable use" or "intragenerational equity")

(4) The need to ensure that environmental considerations are integrated into the economics of development plans, and also the inclusion of development needs in the application of environmental objectives (the principle of "integration").

From the foregoing, therefore, the Principle of Intergenerational Equity emphasizes the preservation of natural resources for the benefit of future generations. Clearly, this principle derives from the Preservationism Movement in the United States of America. Presently, though, although the principle is still based on Preservationism, the application has been modified to be compatible with the prevalent 'use value.' Moreover, the logic of the modification is convincing given the fact that Preservationism championed and hugely succeeded in the limited sphere of preserving US Federal Reserve lands and National Parks. The present realities have expanded the principle beyond the original limited sphere and now include all known human resources. In essence, the principle encourages the exploitation i.e. 'use' of natural resources with a reminder to reasonably do so in consideration of the future generation i.e. 'use values.'

The Principle of Sustainable Use also clearly derives from the Conservationism Movement in the United States. Under this principle, the goal is to exploit the natural resources i.e. 'use' with a careful safeguard against the non-sustainable practices of human beings i.e, 'use values.'

The Principle of Equitable Use or Intragenerational Equity derives from the Conservationism Movement. Here, the emphasis is on the enjoyment or consumption of finite natural resources i.e. 'use', taking into consideration the competing needs of others to the same resources i.e. 'use values.' This principle ostensibly addresses the excessive and disproportional consumption of natural resources by the Western or developed world in contrast to the rest of the world.

The Principle of Integration again derives from the Conservationism Movement. The idea is to encourage the integration of environmental considerations into development plans and vice versa. In other words, both environmental considerations and development plans are complementary partners in a genuine effort at achieving sustainable development. Here, also, this principle seeks to address the popular accusation that the developed countries through their economic agents represented by the trans-national corporations (TNCs) are insensitive to the environmental consequences of their activities.

\subsection{Legal}

The legal origin of the concept of sustainable development can be traced to the earliest efforts by the courts to protect the right of others to the use and enjoyment of natural resources in the form of property rights or environment (Note 18). This legal protection is expressed in the maxim, 'sic utere tuo at in alienum non leadas', which translates as 'so use your own as not to harm another.'

While commenting on this development, Julian Morris argued that when, “...applied in the courts of law, this rule would protect not only the property of the owner but also neighboring properties and even the environment - and society - as a whole" (Note 19). Although the St. Helen's Smelting Co (Note 20) case was decided in the nineteenth century, it was not until the twentieth century that the case of Donoghue v Stevenson (Note 21) popularised the duty of care principle (Note 22). Since Donoghue, the duty of care principle has been applied with vigour in the environmental protection campaign.

\section{Application under Nigerian Laws}

Like all developing countries, Nigeria was faced with the dilemma of pursuing development efforts at the expense of environmental degradation or adopting environmentally safe practices at the expense of faster development. Some critics adduced ulterior motives to the concept by alleging that it was meant to slow development in the developing countries under the guise of environmental consciousness and concluded that it is an extension of the neo-liberalist ideology (Note 23). Perhaps, in realization that the country can not successfully pursue any of the 'needs' goal to the exclusion of the other, the government has embraced the concept of sustainable development.

Consequently, Nigerian laws have risen to the challenge of ensuring that the country's natural resources are harnessed in a sustainable manner. Starting with the Constitution (Note 24), which mandates that, "The State 
shall protect and improve the environment and safeguard the water, air and land, forest and wildlife of Nigeria" (Note 25). The only handicap to this constitutional provision is that it comes under Chapter II on Fundamental Objectives and Directive Principles of State Policy. These objectives are not enforceable in the Nigerian courts and thus lack justiciability. Section 6(6) of the Nigerian Constitution makes all the provisions of Chapter II non-justiciable under the Nigerian courts. In the case of Bishop Anthony Okogie (Trustee of Roman Catholic Schools) \& Ors v. Attorney General Lagos State, (Note 26) it was held that the provisions of the Fundamental Objectives and Directive Principles of State Policy are unenforceable under the Nigerian courts.

The primary environmental law in the country, the NESREA Act, also strives to ensure that the Nigerian environment and natural resources are developed in a sustainable manner. Section 2 of the Act stated the objectives of the enforcement Agency as follows:

"The Agency, shall, subject to the provisions of this Act, have responsibility for the protection and development of the environment, biodiversity conservation and sustainable development of Nigeria's natural resources in general and environmental technology, including coordination and liaison with relevant stakeholders within and outside Nigeria on matters of enforcement of environmental standards, regulations, rules, laws, policies and guidelines" (Emphasis added)

The Act also under Section 7, enumerated the functions of the Agency, which are geared towards sustainably developing the natural resources of the country. Under Section 7 (e), for instance, the Agency is empowered to:

"enforce compliance with guidelines and legislations on sustainable management of the ecosystem, biodiversity conservation and the development of Nigeria's natural resources."

Further, pursuant to the Principle of Integration, the Act mandates the Agency to:

"ensure that environmental projects funded by donor organisations and external support agencies adhered to regulations in environmental safety and protection."

In the same vein, another environmental law (Note 27) insisted that environmental impact assessment should be carried out and be approved before the commencement of any developmental project which is likely to have significant effect on the environment. Such effects could be physical, biological, economic and social. Section 1 of the Act stated that one of the objectives of the environmental impact assessment is:

(a) to establish before a decision taken by any person, authority, corporate body or unincorporated body including the Government of the Federation, State or Local Government intending to undertake or authorise the undertaking of any activity that may likely or to a significant extent affect the environment or have environmental effects on those activities shall first be taken into account.

Although the Act did not clarify what amounts to 'significant effect', however, a further reading of 'environmental effect' provides a reasonable clue. Under the Interpretation section of the Act, 'environmental effect' was defined as follows:

(a) any change that the project may cause to the environment, whether any such change occurs within or outside Nigeria, and includes any effect of any such change on health and socio-economic conditions.

The determination of whether a project could have a 'significant effect' or 'environmental effect' rests with a review panel set up specifically to make such a determination. It is worthy of clarification at this juncture, that the initial Agency charged with the enforcement of the EIA Act was the Federal Environmental Protection Agency, which was established under the FEPA Act. As we have noted earlier, the NESREA Act has repealed the FEPA Act, consequently; the NESREA Agency has inherited the enforcement of the EIA Act.

Another point worthy of clarification is the thesis that the concept of sustainable development applies exclusively in the international environmental law jurisprudence. As Johnston, C.N. et al (Note 28), put it, "the term has been used particularly to describe the goals of international environmental law." Implicit in this perception is the growing tendency by commentators on the concept to unduly focus their intellectual attention on the roles of the trans-national corporations (TNCs) in degrading the environment of developing countries.

Whilst we appreciate the reason and sentiment that propel this perception, albeit a limited one, we contend that the concept is no less applicable in the domestic environmental law arena. Our research so far reveals that at the inception of the 'sustainable development battle' between the Preservationists and the Conservationists in the US, the arena remained local. Moreover, we have also highlighted key provisions in Nigeria's leading environmental laws in proof that the concept also applies with equal force to domestic environmental law. Therefore, it is our position that the concept of sustainable development applies, mutatis mutandis, in both the international and domestic environmental law arenas.

\section{Pros and Cons of the Concept}

Every debate commands two opposing views. The sustainable development debate is no exception. Infact, the fierce 'battle of ideas' that raged between the Preservationists and the Conservationists has presently been inherited by the Positivists/Optimists and the Negativists/Pessimists. This is notwithstanding their commonality 
of purpose - environmental sustainable development. The crux of the disagreement, therefore, does not lie in the concept; but rather in the use to which the opposing camps apply the concept.

Thus, the Posistivists/Optimists view and apply the concept in a positive and optimistic light. Rather than dwell on the limitedness or 'finiteness' of natural resources, they see the 'infiniteness' or limitless natural resources, especially the renewable ones (Note 29). With respect to the non-renewable resources (Note 30), they counter doomsday prophecies with faithful prophecies of the ingenuity of mankind to change their lifestyle or invent alternatives. In this light, the theory of recreationism (Note 31) has been proposed. Simply put, this theory can be summarized as "replenish what you use theory." This theory places a responsibility on individuals to recreate or replenish what they use from the environment. As attractive as the theory of recreationism may appear, it is fraught with a lot of shortcomings, particularly, with respect to finite and non-renewable resources.

Whilst the Negativists/Pessimists lament the wasteful practices of the developed world and their economic agents --the trans-national corporations (TNCs) - the Positivists/Optimists trumpet the principle of 'closing the loop' (Note 32). Indeed, by the application of closing the loop principle, the Positivists/Optimists see the maximization of resources while the Negativists/Pessimists get stuck with the idea of industrial waste.

Since the adoption of the definition of sustainable development from the popular Brundtland Report, the battle has not abated. Even though the Report emphasized development that meets both the present and future needs, yet the Negativists/Pessimists insist on restricting development in the name of sustainable development. As can be predicted, the Positivists/Optimists, on the contrary, insist on promoting development for the benefit of both the present and future generations.

Regardless of the hair-splitting by the extremists on both sides of the divide, Nigeria, like most developing countries has come to the realization that the seemingly contradicting 'needs' dilemma can actually be successfully addressed by a holistic application of the concept of sustainable development. By so doing, both the needs for development as well as environmental consciousness can be guaranteed. In the same vein, the needs of the present as well as the needs of the future generation can equally be guaranteed. Thus, it becomes a win-win situation for all the contesting interests.

\section{Conclusion}

The sustainable development debate will not end soon, certainly not with this work. However, while it continues, we have hopefully contributed to the debate by exposing the essential characteristics of the debate.

The summary is simply that one side claims to speak for "the environment, consumers, the poor and the sick." This side, we have conveniently called the Negativists/Pessimists, argue that "people in the rich world consume too great a proportion of the world's resources and emit too great a proportion of the world's pollution..." Consequently, the recommended solution by this group "is to impose swingering restrictions on the use of resources, wide-ranging interventions in the governance and behaviour of multinational companies and restrictions on international trade."

However, the other side, the Positivists/Optimists, argue that the rich world and indeed the trans-national corporations (TNCs) are actively working to improve their overall standard of living and operational strategies, respectively, by implementing sustainable development practices. This, they argue, is manifested in the zeal with which they have institutionalized and enforced "property rights, the rule of law, free markets, limited government and free speech." Their argument is premised on the defense that the rich world is rich because they adopted sustainable development institutions, not necessarily because they exploit and consume a disproportionate share of the world's resources. Contrary to that allegation, they counter that the poor world is poor due to their inability or unwillingness to adopt sustainable development policies and institutions. They point, and most convincingly so, to the common trend that runs from Africa to Latin America and to the Soviet Union.

With particular reference to Nigeria, we have exposed the legislative aspirations to pursue a sustainable development of the country's natural resources. We hope that the government and the policy makers will match the lofty aspirations with the establishment of the requisite institutions, which will give meaning to the legislative aspirations. Government can begin the process by integrating economic, environmental and development goals in a way that promotes sustainable development. In order to achieve maximum result, all the environmental protection agencies, both at the federal and state level, must be employed in the effort. Also, in order to accelerate the objective, government may have to adopt a policy shift which emphasizes 'environmental management' rather than 'environmental protection' (Note 33) This will, indeed, promote the principle of closing the loop whereby the emphasis will shift solely from regulating the release of industrial waste to the encouragement of innovative ideas on how they can be put to secondary use.

The need for government to embark on massive education campaigns on the benefits of imbibing sustainable development practices cannot be over-emphasized. The United Nations has taken the initiative by declaring the year 2005-2014 as the UN Decade for Education for Sustainable Development. Further, there is need for the government to pursue poverty alleviation policies geared towards ameliorating extreme poverty in the country. The less desperate the citizens are, the more amenable they will be to imbibing sustainable development practices. 
The developed world and the trans-national corporations (TNCs) should encourage and support the country in its effort to establish the culture of sustainable development. Such a partnership will inevitably serve the mutual self-interests of both parties.

\section{References}

Atsegbua, L.A., et al. (2004) Environmental Law in Nigeria. Ababa Press, 57-58

Beckwith, T.J. (2004) Environmental Law. Sweet \& Maxwell, 46

Constitution of the Federal Republic of Nigeria, 1999 (Promulgation) Decree No 24

Johnston, C.N., et al (2005) Legal Protection of the Environment. Thomson/West, 2

Malcom, R.A. (1994) Guidebook to Environmental Law. Sweet \& Maxwell, 12

Morris, J (Ed) (2002). Sustainable Development: Promoting Progress or Perpetuating Poverty.? Profile Books, 256

Morris, Julian, ed (2002) Sustainable Development: Promoting Progress or Perpetuating Poverty? Profile Books, 256

National Environmental Standards and Regulations Enforcement Agency (Establishment) Act, 2007

The United Nations Environment Programme (UNEP). Available: http://www.unep/org/unep/sub 1.htm (May 20, 2010)

Notes:

Note 1. As early as the sixth century BC, Plato had raised alarm at the 'unsustainable development' farming practices of his countrymen in Attica. See Sustainable Development: Promoting Progress or Perpetuating Poverty? (Julian Morris, ed) Profile Books, 2002, 256. See also the remarks of Tertullian in AD 200 when he lamented that "...we men have actually become a burden to the earth, the fruits of nature hardly suffice to sustain us. There is a general pressure of scarcity giving rise to complaints, since the earth can no longer support us. Need we be astonished that plague and famine, warfare and earthquake come to be regarded as remedies, serving, as it were, to trim and prune the superfluity of population. This was quoted by Nisbet (1980), p.52 and referenced by Julian Morris.

Note 2. See the Report of the Experts Group on Environmental Law of the World Commission on Environment and Development, entitled, 'Our Common Future'. See WCED (1987) P. 43

Note 3. See Morris, J (ed), Sustainable Development: Promoting Progress or Perpetuating Poverty? Profile Books, 2002, p. 255

Note 4. See Morris, J (ed), Sustainable Development: Promoting Progress or Perpetuating Poverty? Profile Books, 2002, p. 255-256

Note 5. For further reading on the United Nations Environment Programme, visit http://www.unep/org/unep/sub 1.htm, accessed May 20, 2010

Note 6. For further reading, see Atsegbua, L.A., et al, Environmental Law in Nigeria, Ababa Press, 2004, 57-58

Note 7. Judge Nagendra Singh was the President of International Perspectives in his foreword to the Report of the Experts Group on Environmental Law of the World Commission on Environment and Development (WCED).

Note 8. The report was entitled 'Our Common Future'. See WCED (1987) p.43

Note 9. See Malcom, R., A Guidebook to Environmental Law, Sweet \& Maxwell, 1994, p.12

Note 10. The National Environmental Standards and Regulations Enforcement Agency (Establishment) Act 2007, which repealed the FEPA Act.

Note 11. 331 DHL 1982, cited by Atsegbua, L.A., et al, supra

Note $12.6^{\text {th }}$ edition

Note 13. Johnston, C.N., et al, Legal Protection of the Environment, Thomson/West, 2005, p.2

Note 14. Johnston, C.N., et al, Legal Protection of the Environment, Thomson West, 2005, p.2

Note 15. Quoted by Gifford Pinchot, the father of the United States Forest Service and leader of the Conservation movement.

Note 16. Gifford Pinchot, supra

Note 17. Beckwith, T.J., Environmental Law, Sweet \& Maxwell, 2004, p.46

Note 18. St Helen's Smelting Co v Tipping (1865) 11 All ER 1483. Cited by Julian Morris, supra

Note 19. See the St Helen's Smelting Co v Tipping, supra

Note 20. See the St Helen's Smelting Co v Tipping, supra 
Note 21. (1932) A.C. 562

Note 22. The duty of care standard provides that a person owes a duty to take care not to injure others by his acts or omissions. In the environmental context, it's goal is to re-enforce the environmental law principle that the polluter pays. Under the UK EPA Act, the duty of care serves the following specific goals:

(a) to prevent the commission of the statutory offences;

(b) to prevent the escape of waste;

(c) on transfer, to make sure it is transferred to an authorised person;

(d) to ensure that a written description goes with the waste so that others can comply with the duty.

The only groups exempted from this duty are the householders and their household waste.

Note 23. Boff, L. "(Un) sustainable Development”, Vol. 1, The Independent Weekly, April 30, 2003. See also, http://www.mwillett/org/politics/sustainable.htm

Note 24. The current Constitution of Nigeria is the 1999 Constitution which was promulgated as the Constitution of the Federal Republic of Nigeria (Promulgation) Decree No. 24

Note 25. For further reading, see section 20 of the 1999 Constitution of the Federal Republic of Nigeria

Note 26. (1981) 2 NCLR, 337 CA. The case was decided under the 1979 Constitution. Section 13 of the 1999 Constitution is impari material with section 6 (6) (C) of the 1999 Constitution.

Note 27. Environmental Impact Assessment Act 1992

Note 28. See Johnston, C.N., et al, supra, Legal Protection of the Environment Thomson/West, 2005, p.2

Note 29. For example, timber, fisheries, livestock, species, etc.

Note 30. For example, coal, oil and gas

Note 31. This theory was developed by Nathaniel Uche of the Law Faculty, University of Benin

Note 32. Loop-closing is the idea that the by-products of one industry can become the valuable inputs of another. This idea has been promoted recently by 'industrial ecologists' and 'natural capitalists.' For further reading, see Julian Morris, supra

Note 33. Such a policy shift will be in consonance with the prevailing goal of sustainable development. 